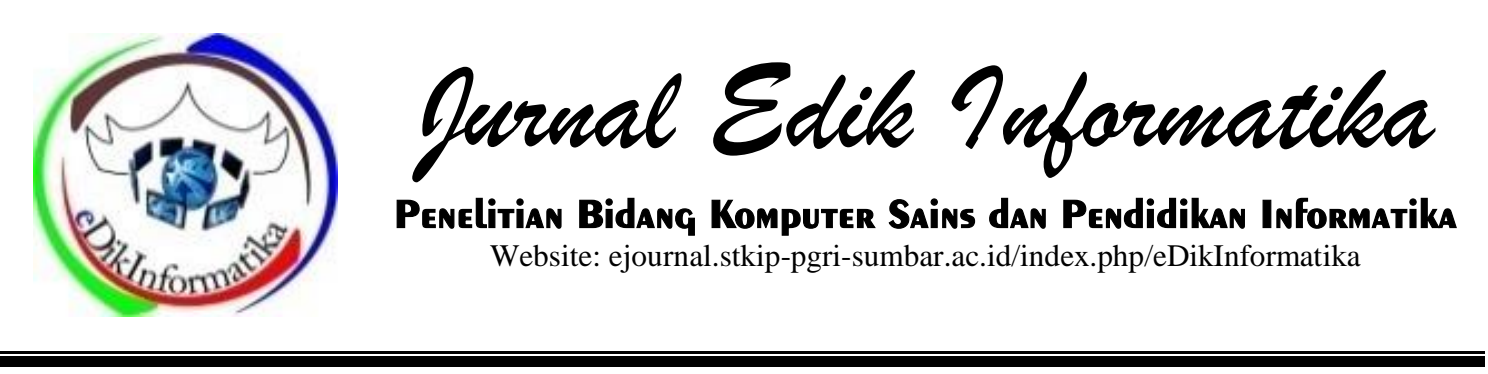

\title{
KORELASI PENGALAMAN PRAKTIK KERJA INDUSTRI TERHADAP KESIAPAN SISWA MENGHADAPI DUNIA KERJA
}

\author{
Sofia Edriati $^{1}$, Ade Pratama ${ }^{2}$, Maini Hikmawati Masril ${ }^{3}$ \\ ${ }_{1,2,3}$ STKIP PGRI Sumatera Barat \\ sofiaedriati81@gmail.com
}

\section{INFO ARTIKEL}

\section{Diterima:}

01 Februari 2020

Direview:

16 April 2020

Disetujui:

29 April 2020

\section{Keywords:}

Pengalaman Prakerin, Kesiapan Menghadapi Dunia Kerja

\begin{abstract}
Industrial work practices can form constructive mindsets for students, especially in preparing themselves for the world of work. This study aims to determine the correlation between experiences of industrial work practices with the readiness of students in dealing with the world of work. This research is a correlation study. This research was conducted at the SMKN 6 Padang with 30 students as a subject of class XII TKJ. The instrument used was a questionnaire of work practices experiences and work readiness questionnaire. The data analysis technique used is simple linear regression analysis. The results of data analysis show that there is a positive correlation between the experiences of industrial work practices with the work readiness of students.
\end{abstract}

\section{PENDAHULUAN}

Praktik kerja industri merupakan program pembelajaran bagi siswa SMK yang dilaksanakan di dunia usaha atau dunia industri dalam rangka meningkatkan kompetensi dan menambah pengalaman bagi siswa dalam mempersiapkan diri untuk memasuki dunia kerja. Sebagaimana diatur dalam keputusan menteri pendidikan dan kebudayaan No.080/V/1993 tentang kurikulum SMK yang menyebutkan tentang pelaksanaan kelompok mata pelajaran keahlian kejuruan sepenuhnya di masyarakat dunia usaha dan dunia industri. Kurikulum SMK dirancang untuk mempersiapkan lulusan agar langsung siap kerja atau mampu membuka lapangan usaha sendiri.
Salah satu tujuan pelaksanaan praktik kerja industri bagi siswa adalah memberikan pengalaman langsung bekerja di dunia usaha atau dunia industri yang sesungguhnya sesuai dengan tujuan SMK yaitu menyiapkan siswa untuk dapat langsung bekerja setelah menamatkan pendidikannya. Kegiatan praktik kerja industri ini juga memberikan pengetahuan kepada siswa terkait bidang pekerjaan yang sesuai dengan disiplin ilmu mereka. Dengan demikian, diharapkan lulusan SMK dapat bekerja sesuai dengan bidang ilmunya.

Lulusan SMK yang bekerja tidak sesuai dengan bidang ilmu masih banyak ditemukan saat ini. Ketidaksesuaian bidang ilmu dengan pekerjaan yang ditekuni salah satunya dapat disebabkan 
oleh kurangnya pengetahuan siswa tentang bidang pekerjaan yang relevan dengan bidang keilmuannya. Hal ini dapat berdampak pada ketidaksiapan siswa dalam memasuki dunia kerja. Penelitian Andri, Syahza, dan Hendripides (2014) dalam penelitiannya menyebutkan bahwa pengalaman siswa dalam melaksanakan prakerin sangat berpengaruh terhadap kesiapan kerja siswa, siswa dengan pengalaman kerja baik memiliki kesiapan kerja yang lebih baik daripada siswa yang pengalaman kerjanya yang kurang.

Praktik kerja industri merupakan suatu kegiatan pelatihan produktif yang wajib diikuti oleh setiap siswa SMK. Kegiatan praktik dilakukan dan dilaksanakan di dunia kerja yang sesungguhnya. Kegiatan praktik ini bertujuan untuk meningkatkan kecakapan siswa dalam bidang pekerjaan tersebut. Kusnaeni \& Martono (2016) menyebutkan bahwa pengalaman kerja bagi siswa akan bermanfaat setelah lulus dari sekolah untuk menyiapkan diri dalam memasuki dunia kerja. Pengalaman kerja siswa melalui praktik kerja industri akan memberikan kesempatan kepada siswa untuk belajar ataupun berlatih secara langsung tentang pekerjaan yang akan ditekuninya sesuai bidang keahlian siswa.

Kesiapan kerja adalah suatu kemampuan yang dimiliki oleh peserta didik untuk dapat langsung bekerja setelah lulus dari SMK, yang meliputi kematangan fisik, kematangan mental, serta pengalaman yang didapat. Siswa SMK harus dipersiapkan untuk mampu menghadapi dunia kerja yang sesungguhnya yang jelas jauh berbeda dengan lingkungan sekolah. Lulusan SMK harus mampu bersaing dan berhasil dalam melalui pekerjaan sesuai bidang ilmu mereka. Siswa SMK harus dipersiapkan untuk menghadapi real job yang ada di dunia usaha dan industri, yang mana mereka akan berada dalam lingkungan yang berbeda dengan lingkungan sekolah yang selama ini mereka hadapi.

Kesiapan siswa dalam memasuki dunia kerja dipengaruhi oleh faktor internal dan eksternal. Faktor internal yaitu mencakup prestasi, pengetahuan, keterampilan dan kesiapan mental yang dimiliki oleh siswa itu sendiri sesuai dengan kompetensi keahliannya masingmasing. Sedangkan faktor eksternal yaitu mencakup dari luar diri siswa, meliputi peran sarana dan prasarana sekolah, keluarga, masyarakat, informasi dunia kerja, serta pengalaman kerja. Berdasarkan uraian di atas, penelitian ini bertujuan untuk mengetahui apakah terdapat korelasi antara pengalaman praktik kerja industri dengan kesiapan siswa menghadapi dunia kerja.

\section{METODE}

Penelitian ini merupakan penelitian korelasi yang bertujuan untuk melihat hubungan dari dua variabel yang diamati. Populasi penelitian ini adalah siswa kelas XI TKJ SMK Negeri 6 Padang yang berjumlah 30 orang. Instrumen yang digunakan untuk pengumpulan data penelitian ini adalah angket praktik kerja industri dan angket kesiapan kerja. Angket yang disusun telah diuji coba terlebih dahulu dan yang digunakan untuk pengumpulan data penelitian adalah butir angket yang memenuhi kriteria valid dan reliabel.Teknik analisis regresi linier sederhana digunakan untuk melihat korelasi antara praktik kerja industri dengan kesiapan siswa menghadapi dunia kerja. Variabel bebas $(x)$ pada penelitian ini adalah pengalaman praktik kerja industri, dan variabel terikatnya $(y)$ adalah kesiapan siswa menghadapi dunia kerja. 


\section{HASIL DAN PEMBAHASAN}

Sesuai dengan tujuan penelitian yaitu untuk mengetahui apakah terdapat pengaruh pengalaman praktik kerja industri terhadap kesiapan siswa dalam menghadapi dunia kerja digunakan analisis regresi linear sederhana. Analisis dilakukan dengan menggunakan SPSS.

Berdasarkan hasil uji normalitas, uji linearitas, dan uji heteroskedastisitas, data penelitian ini memenuhi persyaratan kelayakan menggunakan analisis regresi linear sederhana. Analisis regresi linear dilakukan dengan bantuan SPSS dengan hasil rangkuman disajikan pada Tabel 1 .

Berdasarkan Tabel 1, diperoleh persamaan regresi $Y=63,52+0,35 X$. Nilai konstanta sebesar 63,52 bermakna kesiapan kerja siswa akan sebesar 63,52 jika praktik kerja nol. Hal ini berarti bahwa kesiapan kerja akan menurun jika tidak ada praktik kerja siswa. Variabel praktik kerja siswa berpengaruh positif terhadap kesiapan kerja siswa dengan koefisien regresi sebesar 0,356. Hal ini menunjukkan bahwa apabila praktik kerja siswa meningkat sebesar $1 \%$ maka kesiapan kerja siswa juga akan meningkat sebesar $0,356 \%$. Nilai signifikan sebesar 0,000 jauh lebih kecil dari 0,05 maka pengaruh praktik kerja siswa terhadap kesiapan kerja siswa sangat signifikan.

Berdasarkan perhitungan SPSS nilai $t$ hitung $=3,48$, sedangkan $p$ value sebesar 0,002 lebih kecil dari 0,05 artinya ada pengaruh signifikan variabel pengalaman praktik kerja siswa terhadap kesiapan menghadapi dunia kerja. Ini menunjukkan bahwa semakin baik praktik kerja siswa maka semakin baik juga kesiapan siswa dalam menghadapi dunia kerja.

Koefisien determinasi $R$ square sebesar 0,303 berarti 30,3\% variasi pada kesiapan kerja siswa dapat dijelaskan oleh variabel praktik kerja siswa. Sisanya sebesar $69,7 \%$ dipengaruhi oleh variabel yang tidak dijelaskan dalam model tersebut. Dengan demikian dapat disimpulkan bahwa "pengalaman praktik kerja industri berpengaruh positif terhadap kesiapan kerja siswa".

Berdasarkan analisis data yang telah dilakukan terhadap data pengalaman praktik kerja dan kesiapan kerja siswa, didapatkan bahwa pengalaman praktik kerja industri berpengaruh positif dan signifikan terhadap kesiapan siswa menghadapi dunia kerja. Hasil penelitian ini konsisten dengan hasil penelitian yang dilakukan oleh Lestari \& Siswanto (2015), yang menyatakan bahwa pengalaman praktik kerja industri memiliki pengaruh signifikan terhadap kesiapan kerja siswa.

Temuan penelitian ini relevan dengan penelitian Basuki (2012) yang menemukan ada hubungan yang signifikan antara pengalaman prakerin dengan kesiapan kerja siswa. Hasil penelitian Putriatama, Patmanthara, dan Sugandi (2016) juga menemukan bahwa pengalaman Prakerin berpengaruh positif dan signifikan dengan kesiapan kerja siswa. Hasil penelitian ini juga memperkuat penelitian yang dilakukan Munawaroh, Winarno, dan Sarbini (2016) yang menemukan adanya pengaruh yang positif dan signifikan antara pengalaman prakerin terhadap kesiapan memasuki dunia kerja.

Tabel 1. Hasil Analisis Data Menggunakan Regresi Linear

\begin{tabular}{lcccc}
\hline \multicolumn{1}{c}{ Variabel } & Koefisien Regresi & t hitung & Sig.t & Keterangan \\
\hline Konstanta & 63,52 & 9,51 & 0,000 & \\
Praktik Kerja $(\mathrm{X})$ & 0,35 & 3,49 & 0,002 & signifikan \\
R Square & 0,30 & & & \\
\hline
\end{tabular}


Hasil pengisian angket pengalaman praktik kerja industri oleh siswa pada aspek "menimbulkan pengertian tentang dunia kerja" sangat baik. Siswa dapat memahami dengan baik tugas tentang tanggung jawab di dunia kerja setelah melaksanakan prakerin. Kegiatan prakerin juga membangun kebiasaan kerja, kecakapan kerja, dan sikap kerja yang sangat baik bagi siswa. Siswa juga dapat menciptakan hubungan kerja dengan sangat baik serta bertanggung jawab atas pekerjaannya. Akan tetapi pada aspek menghargai pekerjaan dan para pekerja, siswa masih pada kategori baik.

Kesiapan kerja siswa berdasarkan pada hasil angket berada pada kategori yang sangat baik. Mempertimbangkan dengan logis dan objektif pekerjaan yang sesuai dengan keahlian yang dimiliki. Siswa juga menjalin kerja sama yang baik dengan rekan kerja. Siswa juga mampu mengendalikan diri dan emosi dengan sangat baik. Siswa memiliki sikap kritis yang sangat baik dan memiliki keberanian untuk bertanggung jawab secara individu. Akan tetapi kemampuan beradaptasi dengan lingkungan dan teknologi masih berada pada kategori baik. Pada aspek "mempunyai ambisi untuk maju dan berusaha mengikuti pertimbangan bidang keahlian" siswa sudah pada kategori sangat baik.

Pengalaman praktik kerja industri bagi siswa sangat penting dan kesiapan siswa dalam menghadapi dunia kerja juga sangat diperlukan. Berdasarkan hasil analisis data ditemukan hubungan yang signifikan antara pengalaman praktik kerja siswa dengan kesiapan siswa dalam menghadapi dunia kerja. Dengan kata lain, pengalaman praktik kerja memiliki pengaruh yang positif terhadap kesiapan siswa dalam menghadapi dunia kerja. Oleh karena itu, program praktik lapangan sangat diperlukan untuk melatih kesiapan siswa dalam menghadapi dunia kerja.

\section{KESIMPULAN}

Berdasarkan hasil analisis data dan pembahasan tentang pengalaman praktik kerja industri terhadap kesiapan menghadapi dunia kerja siswa, dapat disimpulkan bahwa pengalaman praktik kerja industri memiliki pengaruh yang positif dan signifikan terhadap kesiapan siswa dalam menghadapi dunia kerja.

\section{UCAPAN TERIMA KASIH}

Terima kasih diucapkan kepada: 1) Bapak Thomson Mary, M.Kom, 2) Bapak Irsyadunas, S.Pd, M.Pd.T, 3) Ibu Ami Anggraini Samudra, S.Pd, M.Sc, dan 4) Reviewer dan editor Jurnal Edik Informatika yang telah memberikan masukan untuk perbaikan penulisan artikel ini.

\section{DAFTAR PUSTAKA}

Andri D, Syahza A., Hendripides. (2014). Pengaruh Praktik Kerja Industri terhadap Kesiapan Kerja Siswa Kelas XI SMKN 2 Pekanbaru. Jurnal Online Mahasiswa Fakultas Keguruan dan Ilmu Pendidikan Universitas Riau. https://media.neliti.com/media/pub lications/201468-pengaruhpraktik-kerja-industri-terhadap.pdf

Basuki. 2012. Korelasi antara Pengalaman Prakerin, Sikap Mandiri dan Prestasi Belajar Bidang Produktif dengan Kesiapan Kerja Siswa Kelas XII Program Keahlian Teknik Mesin (TM) di SMK Negeri 6 Malang. Jurnal Teknik Mesin, 20(2): 1-15

Kusnaeni Y, Martono S. (2016). Pengaruh Persepsi Tentang Praktik Kerja Lapangan, Informasi Dunia Kerja Dan Motivasi Memasuki 
Dunia Kerja Terhadap Kesiapan Kerja Siswa Smk. Economic Education Analysis Journal, 5(2), 519-531.

Lestari I, Siswanto BT. (2015). Pengaruh pengalaman prakerin, hasil belajar produktif dan dukungan sosial terhadap kesiapan kerja siswa SMK. Jurnal Pendidikan Vokasi, 5(2).

https://doi.org/10.21831/jpv.v5i2.6 384

Munawaroh M, Winarno A, Sarbini. 2016. Pengaruh Pengalaman Praktik Kerja Industri dan Prestasi Uji Kompetensi Produktif terhadap Kesiapan Memasuki Dunia Kerja Siswa SMK Negeri 1 Malang. Jurnal Pendidikan Bisnis dan Manajemen, 2(2):143 - 147

Sukmadinata NS. 2016. Metode Penelitian. Bandung: Rosda.

Putriatama E, Patmanthara S, Sugandi RM. 2016. Kontribusi Pengalaman Prakerin, Wawasan Dunia kerja dan kompetensi kejuruan melalui Employability Skill serta Dampaknya terhadap kesiapan kerja Lulusan SMK Kompetensi Keahlian Teknik Komputer dan Jaringan di Probolinggo. Jurnal Pendidikan: Teori, Penelitian, dan Pengembangan, 1(8): 1544-1554 